\title{
$\beta$-Galactosidase activity of commercial lactase samples in raw and pasteurized milk at refrigerated temperatures
}

\author{
T. W. Horner, M. L. Dunn, D. L. Eggett, and L. V. Ogden ${ }^{1}$ \\ Brigham Young University, Provo, UT 84602
}

\section{ABSTRACT}

Many consumers are unable to enjoy the benefits of milk due to lactose intolerance. Lactose-free milk is available but at about 2 times the cost of regular milk or greater, it may be difficult for consumers to afford. The high cost of lactose-free milk is due in part to the added cost of the lactose hydrolysis process. Hydrolysis at refrigerated temperatures, possibly in the bulk tank or package, could increase the flexibility of the process and potentially reduce the cost. A rapid $\beta$-galactosidase assay was used to determine the relative activity of commercially available lactase samples at different temperatures. Four enzymes exhibited low-temperature activity and were added to refrigerated raw and pasteurized milk at various concentrations and allowed to react for various lengths of time. The degree of lactose hydrolysis by each of the enzymes as a function of time and enzyme concentration was determined by HPLC. The 2 most active enzymes, as determined by the $\beta$-galactosidase assay, hydrolyzed over $98 \%$ of the lactose in $24 \mathrm{~h}$ at $2^{\circ} \mathrm{C}$ using the supplier's recommended dosage. The other 2 enzymes hydrolyzed over $95 \%$ of the lactose in $24 \mathrm{~h}$ at twice the supplier's recommended dosage at $2^{\circ} \mathrm{C}$. Results were consistent in all milk types tested. The results show that it is feasible to hydrolyze lactose during refrigerated storage of milk using currently available enzymes.

Key words: lactose-free milk, lactase, $\beta$-galactosidase, lactose intolerance

\section{INTRODUCTION}

Milk is a nutrient-dense food and an important part of a healthy diet. Unfortunately, many consumers are unable to enjoy the benefits of milk due to lactose intolerance (Somkuti and Holsinger, 1997; Choi et al., 2007; Husain, 2010). Lactose intolerance is caused by a deficiency of $\beta$-galactosidase (lactase) in the digestive tract (Panesar et al., 2007). Lactose-free milk is an

Received August 19, 2010.

Accepted March 14, 2011.

${ }^{1}$ Corresponding author: lynn_ogden@byu.edu important product that these consumers have available to provide the nutritional benefits of dairy consumption (Somkuti and Holsinger, 1997). Lactose-free milk is commercially prepared by allowing $\beta$-galactosidase enzymes (EC 3.2.1.23) to hydrolyze the lactose present, before packaging.

Although enzyme-altered lactose-free milk is available, it is expensive, and many consumers are unwilling or unable to pay the extra cost. Lopez and Lopez (2009) reported that high-income families are the main consumers of lactose-free milk. The higher cost of lactose-free milk is due in part to the cost of the hydrolysis process used by manufacturers. It is hypothesized that if enzymes were sufficiently active at the temperature of refrigerated milk, the hydrolysis reaction could be carried out under refrigeration during transport or storage in trucks, tanks, or final packaging. By doing this, the cost to manufacture lactose-free milk might be reduced.

The market for lactose-free milk is estimated at 30 to 50 million consumers in the United States alone (Adhikari et al., 2010). Lactose intolerance is more common in some ethnic groups than others (FDA, 2009). Among African Americans and Native Americans it is about $75 \%$; among Asian populations it is about $90 \%$ (FDA, 2009). With such a large potential market for the product, reducing the cost of lactose-free milk could significantly increase its consumption.

Reduction of lactose in milk has been explored using many different methods. Traditionally, soluble $\beta$-galactosidase enzymes are added to milk. Panesar et al. (2007) explored the use of immobilized enzymes. Novalin et al. (2005) describe using an innovative hollow-fiber ultrafiltration process with immobilized enzymes. Another study described using ultrafiltration and concentration by evaporation, and then adding the enzymes to the concentrated permeate and later adding the hydrolysate back to the retentate (Chen et al., 2002).

Lactose-free milk that has been treated with $\beta$-galactosidase is sweeter than regular milk because the resulting combination of glucose and galactose have about $70 \%$ of the sweetness of sucrose, whereas lactose has only $20 \%$ of the sweetness of sucrose (Novalin et al., 2005). Choi et al. (2007) have shown that the resulting 
sweetness can be removed by utilizing nanofiltration and reconstituting the milk. Harju (1989) describes a chromatographic process to separate the lactose from the protein and other components of milk, completely removing lactose without the use of enzymes and without any residual sweetness. However, none of these or other methods reported in the literature have the potential to significantly reduce the cost of producing lactose-free milk compared with traditional methods.

$\beta$-Galactosidase enzymes are commonly harvested from microorganisms such as fungus, yeast, and bacteria; for example, Kluyveromyces lactis is a commonly used yeast for producing $\beta$-galactosidase in the dairy industry (Dabhole and Joishy, 1998). Enzymes sourced from yeast or bacteria are well suited for the hydrolysis of lactose in milk, often displaying an activity optimum near the $\mathrm{pH}$ of milk (Chen et al., 2009). A fungal $\beta$-galactosidase is typically used in acidic dairy applications, such as sour cream (Chen et al., 2009).

Several bacterial $\beta$-galactosidase enzymes, having optimum hydrolytic activity at temperatures lower than is normal for lactase enzymes, have been isolated (Fernandes et al., 2002; Coker and Brenchley, 2006). Many lactases have optimum temperatures above $30^{\circ} \mathrm{C}$, whereas cold-active lactases can have temperature optimums of $15^{\circ} \mathrm{C}$ or below (Coker and Brenchley, 2006). Bacteria adapted to colder climates can be found in soil and isolated for $\beta$-galactosidase production (Coker et al., 2003). Cold-active $\beta$-galactosidase has also been isolated from psychrophilic yeasts, which may be suitable for food use (Husain, 2010). Thus, it would be beneficial to identify lactase enzymes with significantly greater activity at refrigerated temperatures than those that are currently commercially available.

The objective of this research was to compare the activities of commercially available lactases in refrigerated milk to evaluate their potential for use in a commercial hydrolysis process within a 12 - to 72 -h period.

\section{MATERIALS AND METHODS}

\section{Enzymes}

Five commercially available food-grade $\beta$-galactosidase enzymes were obtained from 4 distributors. The enzymes examined included the following: GODOYNL2 yeast neutral lactase (DYL; Danisco A/S, Copenhagen, Denmark); Validase yeast lactase (VYL) and Validase fungal lactase concentrate (VFL), both from Valley Research (South Bend, IN); Enzeco Lactase NL (EYL; Enzyme Development Corporation, New York, NY); and Lactozym lactase (LYL; Sigma-Aldrich, St. Louis, MO).
The DYL, VYL, and LYL enzymes were derived from K. lactis, EYL enzyme was derived from a Kluyveromyces sp., and VFL was derived from Aspergillus oryzae. The supplier-recommended dosages for the enzymes were $0.1 \%$ (wt/vol) for the DYL, VFL, EYL, and LYL enzymes; and $0.08 \%$ (wt/vol) for the VYL enzyme.

\section{Milk Samples}

The rate of lactose hydrolysis by the enzymes in raw whole milk, pasteurized whole milk, and pasteurized fat-free milk was determined at refrigerated temperature. The raw milk was obtained from the Brigham Young University creamery and originated at the Elberta Valley Agricultural Dairy Farm (Elberta, UT). The composition of the raw milk, as reported by the supplier, was $3.51 \%$ milkfat, $3.11 \%$ protein, and $5.94 \%$ other solids. Raw milk data was determined by using a Lacticheck milk analyzer (Page \& Pedersen International Ltd., Hopkinton, MA). The pasteurized/homogenized fat-free milk and whole milk were obtained from the local market. The fat-free milk had less than $0.5 \%$ milkfat and whole milk had approximately $3.25 \%$ milkfat. Each type of milk was tested using each time and concentration combination (described below), which required the preparation of 65 samples for HPLC analysis for each trial run (195 samples in total for the 3 types of milk).

\section{$\beta$-Galactosidase Assay}

The relative activities of the enzymes were analyzed using a modified version of the $\beta$-galactosidase assay of Miller (1972). To obtain a temperature-activity profile and compare relative activity, assays were carried out at $4,10,20^{\circ} \mathrm{C}$, and ambient (approximately $23^{\circ} \mathrm{C}$ ) temperature. The nonambient temperature trials were performed using a Percival I-36NL controlled atmosphere chamber (Percival Scientific Inc., Perry, IA). As the assay was originally intended for analyzing $\beta$-galactosidase production by bacteria, the assay reagents reacted very quickly when exposed to purified enzyme. To accommodate the higher activity of the commercial enzymes, the samples were diluted $10^{-5}$ (ambient and $20^{\circ} \mathrm{C}$ ) and $10^{-4}\left(4^{\circ} \mathrm{C}, 10^{\circ} \mathrm{C}\right)$ with basal buffer to allow a reaction time similar to the bacterial assay. Approximately 450 $\mu \mathrm{L}$ of basal buffer was combined with $50 \mu \mathrm{L}$ of each enzyme in microfuge tubes $(1.5 \mathrm{~mL})$. Approximately $600 \mu \mathrm{L}$ of assay buffer was then added to each sample and the start time of the reaction was recorded.

Color development was measured at $420 \mathrm{~nm}$ using a spectrophotometer (Milton Roy Spectronic 1001, Milton Roy Instrument Group, Rochester, NY). Samples 
were allowed to react until a faint but stable yellow color developed (between 0.1 and 1.0 on the spectrophotometer). The reaction required 20 to $40 \mathrm{~min}$ on average, after which a stop buffer (sodium carbonate) was added to halt the reaction.

Enzyme activity, based on optical density, was calculated as described in Miller (1972). The protein concentration $(\mathrm{mg} / \mathrm{mL})$ of each enzyme preparation was obtained using the Dumas method (Nielsen, 2003). Based on the activity comparisons of the enzymes, 4 out of 5 of the enzymes were sufficiently active at refrigerated temperatures to be evaluated further. The VFL enzyme demonstrated low activity under refrigeration and was not evaluated in milk.

\section{Hydrolysis in Refrigerated Milk}

Duplicate experiments were conducted for each type of milk using 2 different lots. Lactose content was determined after $12,24,48$, and $72 \mathrm{~h}$ of reaction time. Concentrations of $0.25 \times, 0.5 \times, 0.75 \times$, and $1 \times$ were used for DYL and VYL and $0.5 \times, 1 \times, 1.5 \times$, and $2 \times$ were used for EYL and LYL, where $1 \times=$ the supplier's recommended level of enzyme concentration. Greater activity was observed in DYL and VYL compared with EYL and LYL; hence, the higher concentrations for the latter 2 enzymes.

The selected milk was put into 16 flasks $(100 \mathrm{~mL}$ of milk each). Four flasks were used for each enzyme to allow all 4 concentrations to be tested. Once enzymes were added to the flasks and swirled, the samples were stored at $2^{\circ} \mathrm{C}$. Aliquots of $30 \mathrm{~mL}$ were removed at each time point, transferred to $50-\mathrm{mL}$ test tubes with screwon caps, heated to $82^{\circ} \mathrm{C}$, and held for $15 \mathrm{~s}$ to ensure inactivation of the enzymes to stop the hydrolysis reaction. Lactose content was determined by HPLC. The experiment was conducted with each type of milk to determine if the process of pasteurization or the presence of fat would affect the rate of hydrolysis.

\section{HPLC Analysis}

The HPLC method of Wehr and Frank (2004) was used to determine percentage lactose hydrolysis based on disappearance of lactose. Milk or enzyme-treated samples $(10 \mathrm{~g} \pm 0.0030)$ were weighed into $100-\mathrm{mL}$ volumetric flasks using an analytical balance. Sulfuric acid $(1 \mathrm{~mL}$ of $0.9 \mathrm{~N})$ was added using a mechanical pipette. The mixture was swirled to precipitate proteins. Approximately $50 \mathrm{~mL}$ of deionized distilled water was added to the milk-acid mixture and the mixture swirled again. Samples were then brought to volume (100 mL) with deionized distilled water. Each flask was sealed and shaken vigorously for $20 \mathrm{~s}$.
Samples were allowed to stand for at least 5 min., followed by filtering through $0.45-\mu \mathrm{m}$ polytetrafluoroethylene (PTFE) syringe filters (Nalge Nunc International, Rochester, NY). Approximately $1 \mathrm{~mL}$ of each filtered sample was placed in auto-sampler vials and sealed in preparation for HPLC analysis. Lactose analyses were conducted using an Agilent Model 1100 HPLC (Agilent Technologies, Palo Alto, CA) equipped with a Zorbax 70 A carbohydrate column, 5- $\mu \mathrm{m}, 4.6 \times 250 \mathrm{~mm}$ (Agilent Technologies). For comparison purposes, reference samples made from untreated milk were analyzed in the same manner for each run.

The HPLC separation conditions were as follows: gradient mobile phase of $75 \%$ acetonitrile, $25 \%$ water; $30^{\circ} \mathrm{C} ; 1 \mathrm{~mL} / \mathrm{min}$ flow rate; $20-\mu \mathrm{L}$ injection volume; refractive index detector. Data were quantified using external calibration based on a standard curve.

\section{Data Analysis}

Data were analyzed using SAS software version 9.2 (SAS Institute Inc., Cary, NC). A mixed model ANOVA procedure was used. The dependent variable of the model tested for difference from $95 \%$ lactose hydrolysis (i.e., difference from 95\%) with $P<0.05$. Analyses were also run at 98 and $99 \%$ lactose hydrolysis (difference from 98 or $99 \%$ ). The independent variables included time, enzyme concentration, and the time $\times$ concentration interaction.

\section{RESULTS AND DISCUSSION}

\section{Relative Activity of Commercial Enzymes}

In initial activity tests in buffer ( $\beta$-galactosidase assay), DYL and VYL showed steep increases in activity with increasing temperature, whereas EYL, LYL, and VFL were less affected by the temperature range tested (Figure 1). Of the 5 enzymes evaluated at the manufacturers' recommended levels, DYL and VYL showed greater activity than EYL, LYL, and VFL (Figure 1). This may be due to the higher protein concentration of DYL and VYL compared with the other enzyme samples. The VFL enzyme, specified for use in acidic dairy products, had very little enzyme activity compared with the other 4 enzymes, presumably because of its $\mathrm{pH}$ optimum (4.0 to 5.0) not being within the $\mathrm{pH}$ range of native milk (6.6 to 6.8; Validase Fungal Lactase Concentrate Specification, Valley Research, South Bend, IN); VFL was not included in further experimentation.

Lactase enzymes produced by $K$. lactis commonly have a temperature optimum above room temperature. Schneider et al. (1990) found that lactase derived from 


\section{A}

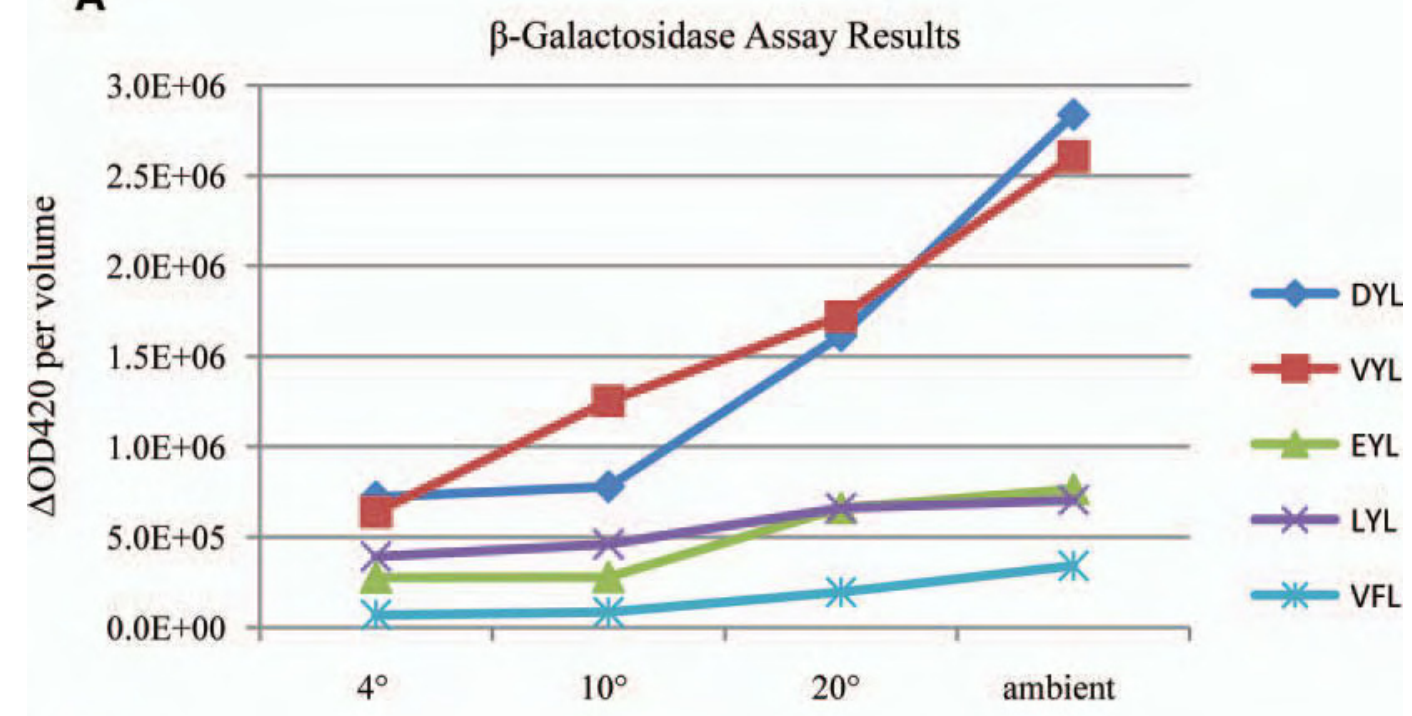

B

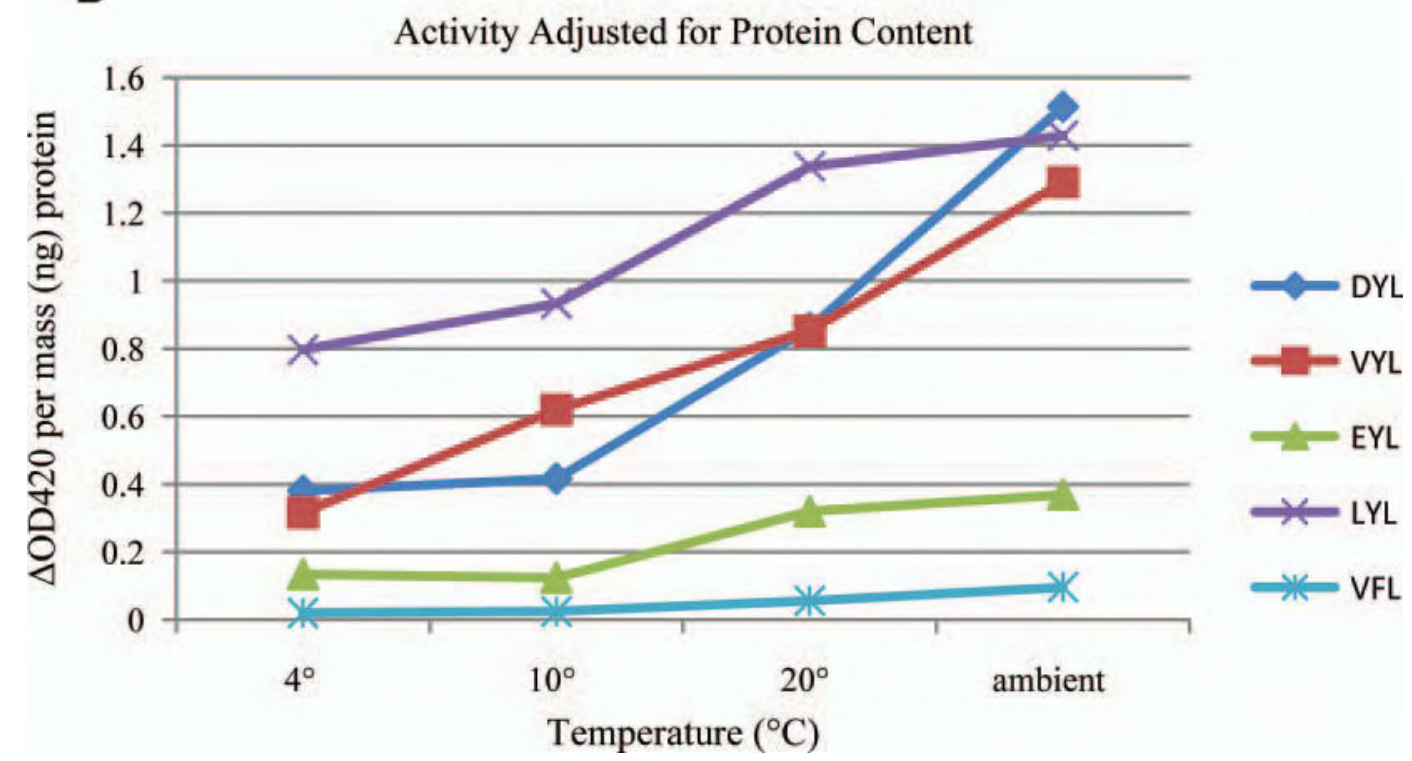

Figure 1. Comparison of $\beta$-galactosidase activity of 5 commercial lactases at different temperatures. Panel A shows the results expressed as change in optical density at $420 \mathrm{~nm}(\Delta \mathrm{OD} 420)$ per minute per volume of enzyme based on the adjusted Miller assay. Panel B shows the $\Delta$ OD 420 per minute per mass (ng) of protein for each enzyme. The mass of protein calculation adjusts for protein content of each enzyme solution and allows for comparison of the efficiency of each enzyme preparation. DYL = GODO-YNL2 yeast neutral lactase (Danisco A/S, Copenhagen, Denmark); VYL = Validase yeast lactase (Valley Research, South Bend, IN); VFL = Validase fungal lactase concentrate (Valley Research); $\mathrm{EYL}=$ Enzeco Lactase NL (Enzyme Development Corporation, New York, NY); and LYL = Lactozym lactase (Sigma-Aldrich, St. Louis, MO). Color version available in the online PDF.

this microorganism had an 85 to $95 \%$ increase in activity at $38^{\circ} \mathrm{C}$ compared with the activity between 4 and $5^{\circ} \mathrm{C}$. Both DYL and VYL showed about a 4-fold increase in activity at ambient temperature $\left(\sim 23^{\circ} \mathrm{C}\right)$ compared with the activity at $4^{\circ} \mathrm{C}$; EYL and LYL showed much more modest increases.

When the results of the $\beta$-galactosidase assay were adjusted for protein content of the enzyme samples [ac- tivity per mass (ng) of protein], the activities of the enzyme preparations were similar to the activities of the enzymes when measured per volume, except for LYL (Figure 1). At refrigeration temperatures, LYL had the highest activity per unit of protein, yet it performed more poorly than the other enzymes during the assay. This is likely due to LYL having the lowest concentration of protein among the enzyme preparations tested, 
Table 1. Time-dependent lactose hydrolysis (\%) in pasteurized whole milk at $2^{\circ} \mathrm{C}$ for 4 selected commercial enzymes at different concentrations ${ }^{1}$

\begin{tabular}{|c|c|c|c|c|c|}
\hline \multirow[b]{2}{*}{ Enzyme $^{2}$} & \multirow[b]{2}{*}{ Concentration $^{3}$} & \multicolumn{4}{|c|}{ Time, $\mathrm{h}$} \\
\hline & & 12 & 24 & 48 & 72 \\
\hline \multirow[t]{4}{*}{ DYL } & $0.25 \times$ & 49.95 & 71.77 & 89.19 & 95.61 \\
\hline & $0.5 \times$ & 75.36 & 89.38 & 98.55 & 99.70 \\
\hline & $0.75 \times$ & 86.43 & 95.72 & 99.99 & 99.86 \\
\hline & $1 \times$ & 92.78 & 99.08 & 99.99 & 99.99 \\
\hline \multirow[t]{4}{*}{ VYL } & $0.25 \times$ & 49.62 & 67.44 & 84.92 & 91.57 \\
\hline & $0.5 \times$ & 67.34 & 88.90 & 98.27 & 99.43 \\
\hline & $0.75 \times$ & 80.00 & 95.29 & 99.54 & 99.81 \\
\hline & $1 \times$ & 90.13 & 98.59 & 99.99 & 99.99 \\
\hline \multirow{4}{*}{ EYL } & $0.5 \times$ & 41.55 & 63.41 & 83.08 & 91.40 \\
\hline & $1 \times$ & 62.29 & 85.23 & 96.67 & 99.05 \\
\hline & $1.5 \times$ & 75.16 & 90.74 & 98.71 & 99.64 \\
\hline & $2 \times$ & 85.86 & 97.32 & 99.99 & 99.99 \\
\hline \multirow[t]{4}{*}{ LYL } & $0.5 \times$ & 39.62 & 58.26 & 79.62 & 88.46 \\
\hline & $1 \times$ & 61.36 & 82.96 & 96.39 & 98.94 \\
\hline & $1.5 \times$ & 74.11 & 91.27 & 99.44 & 99.99 \\
\hline & $2 \times$ & 82.37 & 95.89 & 99.99 & 99.99 \\
\hline
\end{tabular}

${ }^{1}$ The values listed in the table represent the average percentage lactose hydrolysis for the time/concentration pairs.

${ }^{2}$ DYL $=$ GODO-YNL2 yeast neutral lactase (Danisco A/S, Copenhagen, Denmark); VYL = Validase yeast lactase (Valley Research, South Bend, IN); EYL = Enzeco Lactase NL (Enzyme Development Corporation, New York, NY); and LYL = Lactozym lactase (Sigma-Aldrich, St. Louis, MO).

${ }^{3}$ Concentrations represent the fraction of the suppliers' recommended dosages used.

which would result in lower activity levels in the very short (20-40 min) timeframe of the assay.

\section{Lactase Activity in Refrigerated Milk}

To determine lactose hydrolysis in milk for each enzyme, the lactose content of pretreatment milk samples in each trial was compared with the lactose content after treatment. The galactose and glucose peaks eluted at the same retention time during analysis and were inseparable without a specialized column; this was consistent with the results of Sharma et al. (2009). Thus, percentage hydrolysis was determined by disappearance of lactose.

The HPLC lactose peak area of each treated milk sample was divided by the area of the respective untreated milk sample to obtain a percentage of lactose remaining. That percentage was then subtracted from 1 to determine percentage hydrolysis. Percentage hydrolysis of lactose in refrigerated milk varied, depending on the enzyme source, enzyme concentration, and reaction time. Performance of the enzymes correlated well with the results of the $\beta$-galactosidase assay; the enzymes showing greatest activity in the $\beta$-galactosidase assay also hydrolyzed the most lactose in milk.

Percentage hydrolysis for each of the 4 enzymes over time at a series of concentrations is reported in Table 1. Statistics for these values are reported in Table 2. In pasteurized whole milk, DYL hydrolyzed, on average,
$99 \%$ of the lactose present in $24 \mathrm{~h}$ at the supplier's recommended dosage. Enzyme VYL showed an average of $98 \%$ hydrolysis in $24 \mathrm{~h}$ at the supplier's recommended dosage. Both EYL and LYL were able to hydrolyze $95 \%$ of the lactose on average in $24 \mathrm{~h}$, when added at $2 \times$.

Because lactase is a catalyst, lactose hydrolysis can be achieved with less enzyme if the reaction is allowed to proceed for a longer time. Enzyme DYL achieved $95 \%$ average lactose hydrolysis in $72 \mathrm{~h}$ while using onefourth the recommended dosage in pasteurized whole milk and 99\% hydrolysis under the same conditions using one-half the recommended dosage. Enzyme VYL achieved $99 \%$ hydrolysis in $72 \mathrm{~h}$ using one-half of the recommended dosage. Enzymes EYL and LYL both accomplished approximately $99 \%$ hydrolysis on average in $72 \mathrm{~h}$ by using the recommended dosage.

Statistics shown in Table 2 indicate that the target levels of hydrolysis were achieved under the stated conditions. Actual hydrolysis levels were not different from specified target levels, as indicated by the $P$-values. Because the intent of the process was to achieve at least the target level of hydrolysis, $P$-values $>0.05$ are indicative of the target hydrolysis levels being met under the conditions indicated.

\section{Effect of Different Milk Types}

The hydrolysis rate was not affected by fat content or processing. Hydrolysis in raw whole milk, pasteurized 

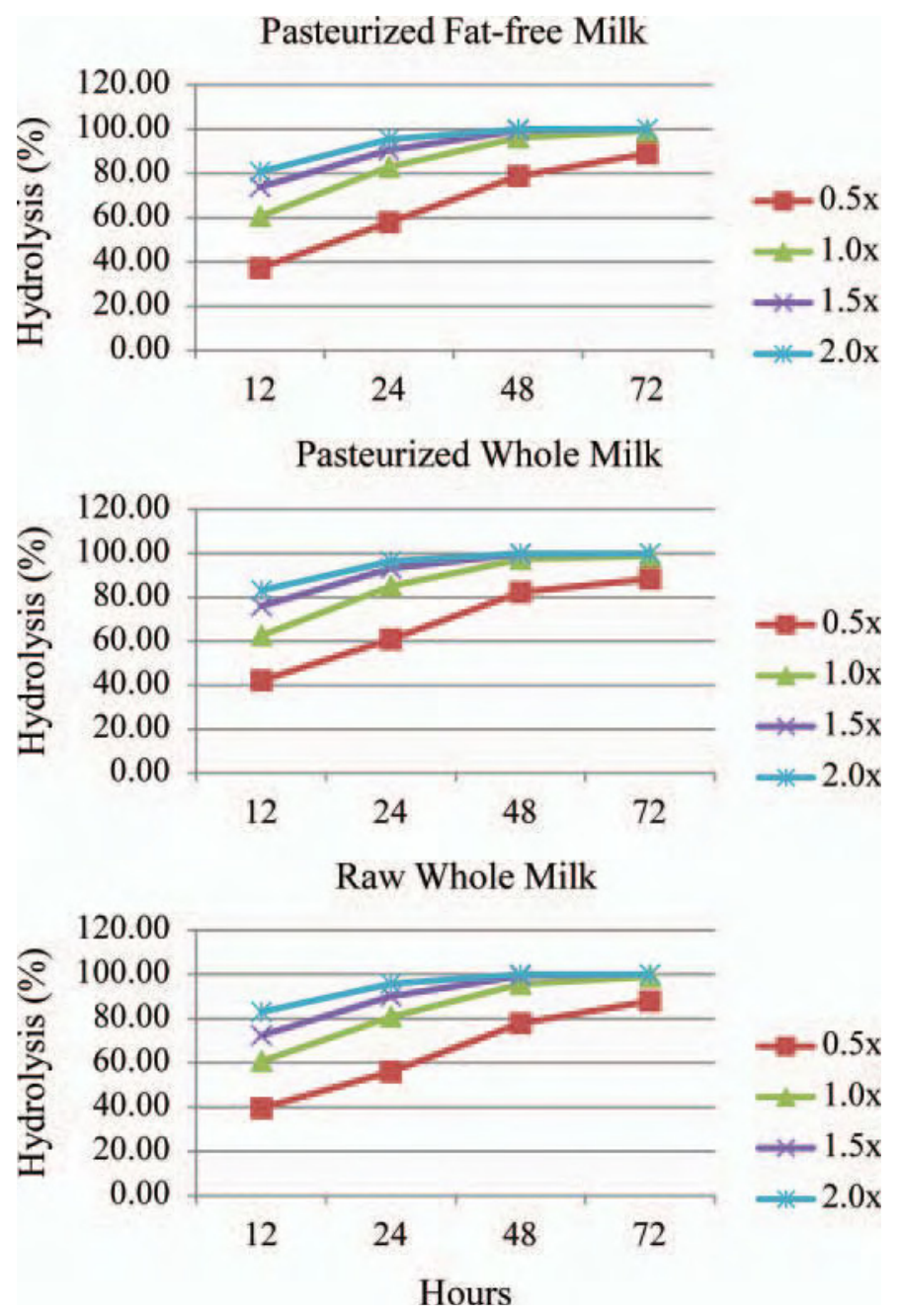

Figure 2. Effects of milk type on enzyme performance of the Lactozym lactase $\beta$-galactosidase (Sigma-Aldrich, St. Louis, MO) at $2^{\circ} \mathrm{C}$. Average percentage lactose hydrolysis is shown. The hydrolysis rate was very similar for all enzymes in all milk types. Color version available in the online PDF.

tion of each enzyme. As the cost increased, the activity also increased. By using a smaller dose and a longer time for lactose hydrolysis, enzyme cost for a liter of lactose-free milk could be minimized.

\section{CONCLUSIONS}

Commercially available lactase enzymes are sufficiently active in milk at refrigeration temperatures to enable the hydrolysis process to be carried out during refrigerated storage. With appropriate time and concentration combinations, $>99 \%$ lactose hydrolysis can be achieved. By facilitating the reaction in milk during cold storage, the hydrolysis process can be simplified with greater flexibility, potentially reducing the cost of manufacturing lactose-free milk. Sweetness in lactose- free milk made by this method is comparable to that of current products on the market. It is not expected that this process will otherwise alter the taste or functionality of the milk. Current lactose-free products indicate the presence of lactase enzyme in the ingredient declaration, indicating that it is an ingredient not used in regular milk. Lactose-free milk processed using the refrigerated holding treatment described here would also be labeled in this way.

\section{REFERENCES}

Adhikari, K., L. M. Dooley, E. Chambers, and N. Bhumiratana. 2010. Sensory characteristics of commercial lactose-free milks manufactured in the United States. Lebenson. Wiss. Technol. 43:113-118.

Chen, C. S., C. K. Hsu, and B. H. Chiang. 2002. Optimization of the enzymic process for manufacturing low-lactose milk containing oligosaccharides. Process Biochem. 38:801-808.

Chen, W., H. Chen, Y. Xia, J. Yang, J. Zhao, F. Tian, H. P. Zhang, and H. Zhang. 2009. Immobilization of recombinant thermostable beta-galactosidase from Bacillus stearothermophilus for lactose hydrolysis in milk. J. Dairy Sci. 92:491-498.

Choi, S. H., S. B. Lee, and H. R. Won. 2007. Development of lactosehydrolyzed milk with low sweetness using nanofiltration. Asianaustralas. J. Anim. Sci. 20:989-993.

Coker, J. A., and J. E. Brenchley. 2006. Protein engineering of a coldactive beta-galactosidase from Arthrobacter sp. SB to increase lactose hydrolysis reveals new sites affecting low temperature activity. Extremophiles 10:515-524.

Coker, J. A., P. P. Sheridan, J. Loveland-Curtze, K. R. Gutshall, A. J. Auman, and J. E. Brenchley. 2003. Biochemical characterization of a beta-galactosidase with a low temperature optimum obtained from an Antarctic Arthrobacter isolate. J. Bacteriol. 185:54735482 .

Dabhole, M. P., and K. N. Joishy. 1998. Beta-galactosidase from the yeast Kluyveromyces lactis. J. Sci. Ind. Res. (India) 57:201-204.

Dattatreya, A., W. Lee, and S. A. Rankin. 2010. Short communication: Presence of galactose and glucose promotes browning of sweet whey powder. J. Dairy Sci. 93:2354-2357.

Fennema, O., S. Damodaran, and K. Parkin. 2008. Fennema's Food Chemistry. 4th ed. CRC Press, Boca Raton, FL.

Fernandes, S., B. Geueke, O. Delgado, J. Coleman, and R. Hatti-Kaul. 2002. Beta-galactosidase from a cold-adapted bacterium: Purification, characterization and application for lactose hydrolysis. Appl Microbiol. Biotechnol. 58:313-321.

Harju, M., inventor. 1989. Process for the specific separation of lactose from milk. Valio Meijerien Keskusosuusliike, assignee. US patent no. $4,820,348$.

Husain, Q. 2010. Beta-galactosidases and their potential applications: A review. Crit. Rev. Biotechnol. 30:41-62.

Lopez, E., and R. A. Lopez. 2009. Demand for differentiated milk products: Implications for price competition. Agribusiness $25: 453-465$.

Messia, M. C., T. Candigliota, and E. Marconi. 2007. Assessment of quality and technological characterization of lactose-hydrolyzed milk. Food Chem. 104:910-917.

Miller, J. H. 1972. Experiments in Molecular Genetics. Cold Spring Harbor Laboratory, Cold Spring Harbor, NY.

Nielsen, S. S. 2003. Food Analysis. 3rd ed. Springer Science+Business Media Inc., New York, NY.

Novalin, S., W. Neuhaus, and K. D. Kulbe. 2005. A new innovative process to produce lactose-reduced skim milk. J. Biotechnol. $119: 212-218$.

Panesar, R., P. S. Panesar, R. S. Singh, and M. B. Bera. 2007. Applicability of alginate entrapped yeast cells for the production of lactose-hydrolyzed milk. J. Food Process Eng. 30:472-484.

Schneider, R. E., E. Corona, F. Rosales, F. E. Schneider, O. Rodriguez, and O. Pineda. 1990. Effect of temperature on the lactose 
hydrolytic capacity of a lactase derived from Kluyveromyces lactis. Am. J. Clin. Nutr. 51:197-201.

Sharma, R., Y. S. Rajput, Poonam, G. Dogra, and S. K. Tomar. 2009. Estimation of sugars in milk by HPLC and its application in detection of adulteration of milk with soymilk. Int. J. Dairy Technol. 62:514-519.

Somkuti, G. A., and V. H. Holsinger. 1997. Microbial technologies in the production of low-lactose dairy foods. Food Sci. Technol. Int. $3: 163-169$.
US FDA. 2009. Problems Digesting Dairy Products? US Food and Drug Administration, Silver Spring, MD. Accessed Jun. 17, 2010. http://www.fda.gov/ForConsumers/ConsumerUpdates/ ucm094550.htm.

Wehr, H. M., and J. F. Frank. 2004. Standard Methods for the Examination of Dairy Products. 17th ed. American Public Health Association, Washington, DC. 